\title{
Several Practices of Teaching Team Construction in Packaging Engineering at China Universities and Colleges
}

\author{
Man-ru Chen, Yu-cong Zhao, Guo-zhi Li, Gui-fen Gong, Yue-qing Xing \\ Dept of Packaging, Shaanxi University of Science \& Technology, Xi'An, China 710021
}

\begin{abstract}
Packaging engineering, one of engineering programs, which is characterized by an interdisciplinary specialty, has been founded in China since the early 1980s. It has well been known that strengthening the construction of its teaching team is of great significance of pushing on the intensive and characteristic development, promotion of teaching quality, as well as the aggressive adaptation of the new normal of higher education. In this paper, taking a comprehensive reform of packaging engineering program of our University as an instance, some systems and practices on the construction of teaching team are focally introduced, inclusive of moral guidance, system and incentives, overall deepening of teaching innovation.
\end{abstract}

Index Terms - teaching team; quality project; engineering education; resource development in teaching

\section{Background to Construction of Teaching Team}

The enhancement of college enrollments implemented nationwide in 1999 has resulted in the popularization of higher education in China, which has accordingly caused the decline in the quality of teaching and the level of talent training so that some educators called it "The Hollow Higher Education". Such appearance is more prominent in "non-211" provincial universities and colleges. For this reason, State put "the Quality Engineering Projects[1]" into effect in 2007 in order entirely to advance the quality in teaching and level of talent cultivation of universities. In October,2007, the teaching team in packaging engineering of our University was awarded such project[2] funded by the Education Department of Shaanxi Provincial Government, which was one of the quality engineering projects advocated in the whole nation. In 2011, the first year of the 12th Five-Year-Plan, our country launched "The Undergraduate Teaching Projects[3]", which clearly stated the integrated innovation must be proceeded to and the internal development must be intensified in such crucial aspects affecting major development as mode of talent cultivation, team of teachers, curriculum \& textbooks, teaching ways, management in teaching, etc.. In the meanwhile, it proposed the reconstruction of national high-quality open courses through encouraging China institutions of higher learning to display the state-of-the art teaching ideology of college teachers, the exclusive teaching means and the abundant achievements in teaching. The requirement of connotative development to improve quality under the new normal of China's higher education shows us an avenue to well establish a sound teaching team and well run our packaging engineering program at undergraduate level. In recent years, we have maintained such concepts of team development as "Moral Guidance, System Security, Policy Incentive,
Interaction Among Teachers, Impulsion of Teaching Innovation, Exquisite Skills", taken teaching as a main line, the advancement of quality as the core and teaching body as the focal point to strenuously give impetus to the build-up of teaching team. Therefore, by means of effective ways, the teaching ability and scientific research diathesis of teachers within team are promoted on the whole. Thus, in light of constructing professional teachers' team with high quality to organize our team, teaching and educating level are greatly improved, which has further raised the reputation of our packaging engineering program all over the China.

Over the years, under the organization and leadership of team leader, some dominant teaching achievements have been acquired as follows. Our packaging engineering program was funded by provincial project in June, 2008 and national project in July, 2010, respectively. Our course entitled "Packaging Technology" was awarded the provincial and national bilingual teaching demonstration courses in October, 2008 and in May, 2010, respectively. In September, 2013, the program was funded by the provincial project "Comprehensive Reform Pilot of Programs(CRPP)", In August, 2014, three subprojects of CRPP were conferred by Shaanxi Government, for example, "Fundamentals of Packaging Technology", an updated high-quality resource sharing course; "Structural Design of Packaging", a new high-quality resource sharing course and "Innovative Talent Training Mode in Experimentation Area". In October, 2013, our packaging program was approved by the Ministry of Education, China as a pilot of "Engineering Education and Training Programs of Excellence". In addition, two provincial projects on integrated teaching innovation have been completed; five teaching achievement awards were granted; ten textbooks[5-6] have been published, where two are the national planning materials; more than thirty papers[7-8] on educational and teaching innovation have been appeared, Simultaneously, our team also attaches importance to interaction of scientific research and teaching, mentoring role with the old, middle-aged and young teachers, training of experimental teaching skill and bilingual teaching skill[9], which in turn obviously facilitates undergraduates' innovation and entrepreneurial ability and comprehensive competitiveness in profession and expansion of international horizon. 


\section{Considerations in Reconstructing Teaching Team}

A. Taking Moral Education As a Breakthrough, Building Atmosphere of Both Teaching and Educating People

In order that the teachers of team are capable of building the concept of occupation, i.e., "Great Learning Makes a Teacher; Moral Integrity Makes a Model”, keeping an upright teaching spirit of their own free will, strengthening their ideology and moral education in profession, strengthening their responsibility and mission of teaching \& educating students, the activities to learn the advanced deeds of excellent teachers at their sides are started, and the roles of party branch, party members and teachers with the senior titles are asked to be fully brought into play, combined with the feedback of suggestions resulted from alumni. The team requires that such norms as "Being Passionate in one's Job, Caring for Students, Being Devoted to Study, Self-Esteemed and Self-Disciplined" be observed, and educating and motivating each student with their moral quality and knowledge charm is conscientiously implemented to all the daily teaching affairs. On the basis of that, the team leader is expected to play an exemplary role in teaching and educating people, and all the team members are demanded to better abide by "Norms of Professional Ethics" stipulated by the University.

\section{B. Taking System Construction As a Guarantee, Innovating Excitation Mechanism To Encourage Teachers' \\ Enthusiasm Involved In Teaching}

The norm, i.e., "The Identification and Interim Managing Procedures of Teaching Accidents of Shaanxi University of Science \& Technology " laid down by University ought not be violated any time. "The University's Measures for the Implementation of Performance Appraisal for Undergraduate Teaching "and College's Incentive Policy On Teaching Performance have the teachers on the teaching work with great concentration and make their endeavor to more teaching achievements. Besides, inside the teaching team has been implementing a full funding of the papers on educational and teaching, of teaching/academic exchange on domestic conferences for the young and writing textbooks, etc. to impel and boost teaching level as a whole.

Meanwhile, the regulation that the chair of packaging department (or teaching and research section ) is taken turns every two years by teacher with senior title is put into effect, thus heightening senior teachers' responsibility and their mentoring role, on the other hand, having more experience in the comprehensive construction of program and the routine management in teaching. There are some available rules like sharing responsibility for teaching process, e.g., practices, graduation project.

\section{Strengthening Communications To Intensify Teachers' Teaching Capability}

1) Diversity of Teaching Experience and Academic Exchange: Team takes pains to open up many channels and means to exchange at home and abroad, participate in highlevel domestic workshop and English language training, and cooperate between college and business to comprehensively promote teachers' professional level. For example, there were three teachers studying in UK, USA on the short-term basis to figure out the advanced teaching concepts and teaching mode. Moreover, many engineering training bases have been created to carry out the bring-up mode of training the application type and multi-functional type talents under the background of "National Engineering Education and Training Programs of Excellence". These diverse communications broaden teachers' vision, comprehend industrial trends, increase exchange with the associates and enlarge the influential power of our packaging program in China.

2) Normalization and Institutionalization of Interaction Among Teachers: First, a system of lectures on special topics is regulated inside teaching team. Any teacher is asked to make a speech towards all the colleagues, seniors and graduates within packaging department after they attend a meeting. Second, mentorship and tutoring system for the young teachers are really practicable. In other words, through coaching them to prepare class, visiting class, giving a lecture and demonstrating class, the young teachers can be able to be made to learn how to grasp instructing skills in terms of educational/teaching rules, teaching design in class, assessment method, and maneuver students' initiatives and motivation. The teaching activities on the regular basis are insisted on to be conducive to enlighten teachers to probe into the creative mode of teaching in classroom, feed in turn disciplinary frontiers into teaching in classroom and enhance the teaching effect in classroom while the consciousness of scientific research is brought up. Nowadays, of team, there are two young teachers obtaining the titles "Academic Backbone for Young Teachers" at university level; there are three persons to win prizes for annual teaching competition for the young of the university.

\section{Boosting Teachers' Engineering and Practical Capability and Quickening Construction of Practice Teaching System}

1) Teachers' Rotation System In Laboratories and Engineering Practice System: The project "National Engineering Education and Training Programs of Excellence" advocated by Ministry of Education is to place students' integrated practice and engineering design ability in a prominent position. For this reason, the primary task is to heighten teachers' capability to make students' one improved. So, teachers' rotations in laboratories and engineering practice system are fulfilled. It is required that each teacher take parttime position in lab for half a year and do internships in the related packaging corporations every three years.

2) Perfecting Practice Teaching System On Campus In Accordance With Requirements of "Engineering Education and Training Programs of Excellence": It is demanded that teachers within team assuming any core courses add the ratio of comprehensive and designing experiments, perfect open system of lab and standardize the syllabus, experimental instruction, time, task, record \& report during practice in production, acceptance check and evaluation \& summary of 
practice teaching process. Meanwhile, the selected topics of graduation project are encouraged to come from engineering fields. Moreover, an assessment and evaluation system for students' performance in which college, employers and industry jointly participate is set up.

3) Positively Moving Forward Construction of Internship Bases and Social Practice of Summer Vacation Off Campus and Building Bases Used for Production, Education and Research: Taking advantage of summer holidays, the teachers, graduates and undergraduates are encouraged to enter the known packaging enterprises for internship for one to two months and take part in production in plant, business and packaging development.

\section{E. Taking Construction of Courses as Basis to Move Forward Comprehensive Innovation Pace of Packaging Engineering Program \\ The team takes the approval "National Bilingual} Teaching Demonstration Course" project as a carrier, accepts the advanced bilingual teaching concept, explores and perfects the effective bilingual education mode conforming to students' attributes and guaranteeing teaching effect. Some new pedagogies adapted to such students majored in engineering at the local universities and colleges, i.e., elicitation, participation, discussion and inquiry methods, are adopted to mobilize students' interests in study and initiatives, which is thus beneficial to fostering packaging professionals towards internationalization.

For the provincial approval new-built high quality resource sharing course, i.e., "Structural Design of Packaging", the integration and construction of teaching resources will be carried through in line with the relevant requirements while another sub-project, i.e., "Experimentation Area for Innovation of Packaging Talents", will be fulfilled in the light of the requirement of approval pilot project "Engineering Education and Training Programs of Excellence". Besides, our team will plan to apply for two provincial new-built high quality resource sharing courses, i.e., "Distribution Packaging" and "Packaging Materials", as well as one project of "Experimental Teaching Center for Packaging Engineering" so that more packaging core courses will be able to become the provincial high-quality resource sharing courses, which can in turn play an excitation and radiation role in program construction. It is believed that the comprehensive innovation of packaging program will surely push on the connotation development level and distinct improvement of teaching quality of our packaging program.

\section{Conclusion}

To suit the new normal of connotative development, quality improvement of higher education, it is an irresistible trend to set up a high-level teaching team. For years, some construction success has been achieved through the exploration and practice of developing teaching team of packaging engineering program. In recent years, many teaching innovation projects and "Undergraduate Teaching Engineering Projects" at the provincial level or above have been completed; more than 30 papers on teaching innovation have been written; many a high-level textbook has been published; and high-quality teaching resources about packaging engineering program to be radiated and shared have already been built (or building) up. Meanwhile, the scientific research projects finished have been a feedback of teaching work. For example, number of student access to labs or attending teachers' scientific research projects has significantly been increased. In addition, the integrated innovation in talent cultivation mode of practical teaching arena is applicable to the background to national "Engineering Education and Training Programs of Excellence" and a system for college and enterprise to jointly bring up packaging professionals is set up. Up to now, more than 20 practical bases of all kinds inside and outside the province have been established one after another.

Through morality education, teaching innovation and creativity, academic exchange and training, and engineering practice, the configuration of teachers not only tends to be rational, but also the comprehensive quality and teaching skills have greatly been improved, thus leading to the fact that the cultivation quality of talents has been heightened. In recent years, a lot of prizes of packaging undergraduates for "Creative Design" of China packaging, National Packaging Structural Design Competition, Appearance Design \& Patents have been achieved. More fresh graduates are admitted to "985" universities such as Wuhan University. Moreover, startup and employment ability has been increased, with the employment rate being up to $90 \%$ for successive years and better average start salary. The packaging graduates are commonly praised by employers for their painstaking and abilities to analyze and tackle the engineering problems.

The teaching team of Packaging Engineering Program of our University has been checked and accepted by Shaanxi Education Department. The construction programme of the team has been fully affirmed. Many a teaching resource of major courses has been open to the public and teachers and students pertinent to packaging engineering and gained a good response. Many teachers from other universities and colleges personally come and are trained or on-the-spot study to learn talents' cultivation programme and cultivation mode. Some packaging companies have set up studentship as well. These associates reckon that "the provincial teaching team of packaging program of Shaanxi University of Science \& Technology is featured by the higher level and productive experience; the team construction sets discipline construction and integrated innovation of the program in motion; the teaching team actively launches teaching innovation and education/teaching research so that the overall teaching level and teaching effect of all the major teachers are effectively improved and cultivation quality of packaging professionals is warranted, thus level of running a program being among the highest in China". 


\section{Acknowledgement}

The authors are quite grateful to The Education Department of Shaanxi Provincial Government for the project Comprehensive Innovation Pilot of Programs (official document No. 15 in 2013) funded.

\section{References}

[1] Official Document No.1 in 2007, "On Suggestion of Implementation of Undergraduate Teaching Quality and Teaching Innovation at Universities and Colleges", Ministry of Education and Ministry of Finance, China, Jan. 2007.

[2] Official Document No.52 in 2007, "On Announcement of 2007 Teaching Teams of Shaanxi Regular Universities and Colleges", Shaanxi Department of Education, Oct. 2007.

[3] Official Document No.6 in 2011, "On Suggestion of Implementation of Undergraduate Teaching Quality and Teaching Innovation at
Universities and Colleges", Ministry of Education and Ministry of Finance, China, Jul. 2011.

[4] Official Document No.8 in 2011, "On Suggestion of Implementation of National High-Quality Open Course Constructions", Ministry of Education, China, Oct. 2011.

[5] M. Chen, Y. Zhao, et al, Academic English for Packaging, Beijing: Graphic Communications Press, Nov. 2013.

[6] M. Chen, D. Sun, et al, Fundamentals of Packaging engineering(Bilingual Teaching) (2nd Edition), Beijing: Chemical Industry Press, 2015.

[7] Yucong Zhao, Yong Ding, Manru Chen, et al, Fostering Innovative \& Entrepreneurial Talents of Packaging Based on Curriculum Construction, ICETIS 2013, pp.372-375, 2013.

[8] Y. Zhao, M. Chen, et al, "Integrating Teaching Resources to Advance Construction of Major's Teaching Team", Education for Chinese Afterschool(Theory), no.9, pp.49-51, 2011.

[9] M. Chen, Y. Zhao, et al, Reform of Bilingual Teaching of Packaging Engineering in China Universities and Colleges, ICETIS 2013, pp.247250, 2013. 